\title{
Ginekomasti pada Laki-Laki dengan Mikroadenoma Hipofisis
}

\section{Gynecomastia in a Man with Hypophysis Microadenoma}

\author{
Dicky Faizal I', Tjahjo Djojo $T^{2}$ \\ ${ }^{1}$ Laboratorium Biokimia Biomolekuler Fakultas Kedokteran Universitas Brawijaya Malang \\ ${ }^{2}$ Klinik Andrologi Rumah Sakit Umum Daerah Dr. Soetomo Surabaya
}

\begin{abstract}
ABSTRAK
Ginekomasti adalah pembesaran payudara laki-laki yang mengacu pada proliferasi komponen duktal. Ditemukan kasus ginekomasti yang jarang terjadi. Seorang pria berusia 44 tahun datang dengan keluhan utama pembesaran kedua payudara sejak tiga tahun terakhir. Pada pemeriksaan fisik, ditemukan ginekomasti kelas II (tanner IV) dengan galaktorhea. Pemeriksaan genitalia menunjukkan panjang penis $10 \mathrm{~cm}$ dan volume testis $6 \mathrm{~mL}$ dengan konsistensi lunak. Nilai testosteron 22,65ng/dL, LH $<0,07 \mathrm{mlU} / \mathrm{mL}$, dan $\mathrm{FSH}<0,3 \mathrm{mlU} / \mathrm{mL}$. Pemeriksaan ultrasonografi (USG) payudara menunjukkan ginekomasti bilateral dengan ektasis duktal bilateral. Ultrasonografi (USG) abdomen menunjukkan tidak ada signifikansi yang terkait ginekomasti. Ultrasonografi (USG) skrotum menunjukkan testis yang normal di kedua sisi. Magnetic Resonansi Imagine (MRI) kepala (dengan kontras) ditemukan mikroadenoma hipofisis. Pasien didiagnosis sebagai ginekomasti dengan mikroadenoma hipofisis. Pasien direncanakan untuk mendapatkan terapi penggantian testosteron.
\end{abstract}

Kata Kunci: Feminisasi laki-laki, ginekomasti, karakteristik seksual sekunder, mikroadenoma hipofisis

\section{ABSTRACT}

Gynecomastia is enlargement of the male breasts refering to ductular component proliferation. A rare case of gynecomastia was found. A 44-year-old man came with a chief complaint of enlargement on both breasts since the last three years. On physical examination, there was gynecomastia grade II (tanner IV) with galactorrhea. The genitalia examination showed the penile length was $10 \mathrm{~cm}$, testicular volume was $6 \mathrm{~mL}$ with soft consistency. The levels of testosterone was 22,65ng/dL, LH $<0,07 \mathrm{~m} / \mathrm{U} / \mathrm{mL}$, and $\mathrm{FSH}<0,3 \mathrm{mIU} / \mathrm{ml}$. The breast ultrasound showed bilateral gynecomastia with bilateral duct ectasia. The abdominal ultrasound showed that there was nothing significant related to his gynecomastia. The scrotal ultrasound showed that both testicles were normal. The head MRI (with contrast) found hypophysis microadenoma. The patient was diagnosed as gynecomastia with hypophysis microadenoma. This patient was planned to obtain testosterone replacement therapy.

Keywords: gynecomastia, hypophysis microadenoma, male feminization, secondary sexual characteristic

Korespondensi: Dicky Faizal I. Laboratorium Biokimia Biomolekuler Fakultas Kedokteran Universitas Brawijaya Malang, Jl. Veteran, Malang 65145 Tel. (0341)569117Email:dr.dicky.faizal@gmail.com

DOI: http://dx.doi.org/10.21776/ub.jkb.2017.029.04.16 


\section{PENDAHULUAN}

Ginekomasti merupakan pembesaran dari kelenjar payudara pada laki-laki. Pembesaran kelenjar yang dimaksud adalah proliferasi, baik unilateral maupun bilateral, yang berasal dari komponen duktular payudara, bukan komponen lemak yang disebut lipomasti (1). Ginekomasti secara fisiologis ditemukan pada laki-laki pada usia tertentu, diantaranya neonatus dengan prevalensi $60-90 \%$, remaja dengan prevalensi $50-60 \%$, dan pada lansia dengan prevalensi mencapai $70 \%$. Pada kondisi ini, ginekomasti dapat menyebabkan kecemasan dan ketidaknyamanan fisik, serta ketakutan munculnya kanker payudara. Pada kondisi patologis, ginekomasti dapat menjadi sebuah petanda dari banyak kondisi endokrin maupun sistemik yang lebih serius. Beberapa kondisi patologis yang dapat menyebabkan ginekomasti adalah sirosis $(8 \%)$, hipogonadisme primer $(8 \%)$, tumor testis (3\%), hipogonadisme sekunder (2\%), hipertiroid $(1,5 \%)$, dan penyakit ginjal (1\%). Patogenesis ginekomasti pada umumnya adalah terganggunya keseimbangan antara androgen dengan estrogen yang masing-masing memiliki reseptor pada kelenjar payudara laki-laki, dengan fungsi estrogen sebagai stimulator proliferasi duktal, dan androgen berperan sebaliknya (3).

Hipogonadisme pada pria merupakan sindrom klinis akibat rendahnya hormon testosteron (defisiensi androgen). Kondisi ini berkaitan dengan poros hipotalamus-hipofisis (4). Maka evaluasi hormon testosteron dilakukan bersama evaluasi hormon gonadotropin, yaitu follicle-stimulating hormone (FSH) dan luteinizing hormone (LH) sebagai penunjang diagnosis. Peningkatan gonadotropin yang disertai rendahnya hormon testosteron disebut hipogonadisme primer. Kondisi ini dapat disebabkan oleh kegagalan testis memproduksi testosteron $(4,5)$. Sedangkan hipogonadisme sekunder adalah kondisi rendahnya kadar hormon gonadotropin dan testosteron dalam darah. Rendahnya hormon gonadotropin dapat disebabkan karena absen atau tidak cukupnya sekresi gonadotropin-releasing hormone (GnRH) pada hipotalamus, atau kegagalan hipofisis dalam sekresi hormon gonadotropin $(5,6)$.

Salah satu penyebab hipogonadisme sekunder adalah tumor pada hipofisis (4-7). Tumor hipofisis adalah tipe kelainan hipofisis yang paling umum, yaitu sekitar $10-15 \%$ dari semua kejadian massa intrakranial (8). Terdapat tipe adenoma hipofisis yang bersifat aktif secara endokrinologi, yaitu kelebihan sekresi hormon hipofisis anterior, dan terdapat tipe yang bersifat non-fungsional, yaitu tidak menimbulkan hiperfungsi endokrin (8). Adenoma hipofisis juga diklasifikasikan menurut ukurannya. Bila ukurannya lebih dari $10 \mathrm{~mm}$, disebut makroadenoma, bila kurang dari $10 \mathrm{~mm}$, disebut mikroadenoma. Mikroadenoma memiliki angka kejadian sedikit lebih besar dibandingkan makroadenoma, yaitu $57,4 \%$ dibandingkan $42,6 \%$ (8).

Pada artikel ini dilaporkan kasus ginekomasti yang disebabkan mikroadenoma hipofisis. Kasus ini jarang terjadi karena mikroadenoma hipofisis menyebabkan hipogonadisme yang tidak hanya memiliki efek pada ginekomasti, namun sampai ke tahap feminisasi.

\section{KASUS}

Pasien merupakan rujukan dari RSU daerah dan datang ke Poli Endokrin rumah sakit rujukan pada 22 Desember 2014 dengan keluhan pembesaran payudara kanan dan kiri sejak 3 tahun terakhir seperti tampak pada Gambar 1. Selama 1 tahun terakhir, diawali dengan rasa nyeri yang hilang timbul, kedua payudara juga mengeluarkan cairan saat ditekan. Tidak didapatkan rasa nyeri atau benjolan yang keras saat diraba. Rambut tubuh seperti kumis, janggut, ketiak, dan bulu kaki rontok sejak 1 tahun terakhir ini. Sebelumnya pasien cukur kumis atau jenggot 1 minggu sekali, namun 3 bulan terakhir ini sudah tidak pernah bercukur. Pasien merasa kulit makin halus dan tidak berambut. Suara pasien dirasakan berubah menjadi lebih halus dan seperti suara wanita. Sebelum keluhan muncul, frekuensi pasien berhubungan badan dengan istri 2$3 x /$ minggu, setelah keluhan muncul nyaris tidak pernah.

Pasien memiliki riwayat kelainan katup jantung dan gangguan irama jantung sejak kecil, namun sering kambuh dan sering keluar masuk rumah sakit dalam 3 tahun terakhir. Pemberian obat selama rawat inap tidak diketahui. Terapi yang dibawa pulang adalah bisoprolol fumarate $1 \times 5 \mathrm{mg}$, aspilet $1 \times 1$ tablet, dan simvastatin $1 \times 10$ mg. Pasien menyangkal pernah menggunakan obatobatan untuk membentuk badan atau suntikan hormonal. Pasien tidak merokok. Pasien tidak memiliki riwayat penyimpangan seksual. Pasien telah menikah (pernikahan pertama) selama 18 tahun dengan tiga anak, yaitu anak pertama berusia 16 tahun, anak kedua 12 tahun, dan anak ketiga 3,5 tahun. Dari lingkungan sosial (bagi yang tidak mengenal) pasien dianggap sebagai perempuan, sehingga kini pasien menggunakan toilet perempuan. Di lingkungan keluarga, terjadi kebingungan akan adanya perubahan fisik yang kian lama kian menyerupai perempuan.
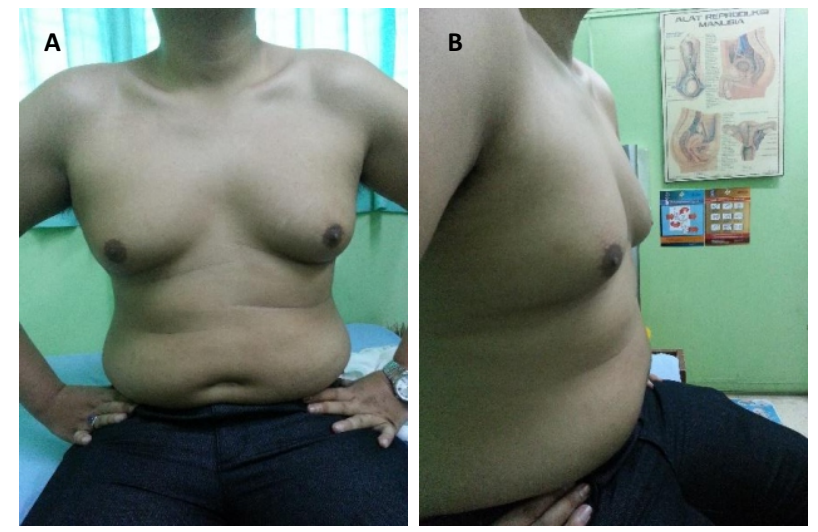

Gambar 1. Foto ginekomasti grade II atau setara dengan tanner IV tampak depan (A) dan tampak samping (B)

Pada pemeriksaan fisik, pasien memiliki tinggi badan 158 $\mathrm{cm}$ dengan berat badan $55 \mathrm{~kg}$. Pada pemeriksaan payudara ditemukan ginekomasti positif grade II (Tanner IV) (3). Galaktorhea positif. Pemeriksaan fisik lain dalam batas normal (Tabel 1).

Tabel 1. Hasil pemeriksaan fisik genitalia

\begin{tabular}{lcc}
\hline & Kanan & Kiri \\
\hline \multicolumn{2}{l}{ Eksterna } & \\
Penis & 10 \\
$\square \quad$ Panjang penis $(\mathrm{cm})$ & 8 \\
$\square \quad$ Lingkar penis $(\mathrm{cm})$ & \\
\hline
\end{tabular}


Tabel 1. Hasil pemeriksaan fisik genitalia (Lanjutan)

\begin{tabular}{|c|c|c|c|}
\hline & & Kanan & Kiri \\
\hline \multicolumn{4}{|c|}{ Eksterna } \\
\hline \multicolumn{4}{|c|}{ Penis } \\
\hline$\square$ & Fibroush plaque & \multicolumn{2}{|c|}{-} \\
\hline$\square$ & Muara uretra & \multicolumn{2}{|c|}{ Posisi } \\
\hline \multicolumn{2}{|c|}{ Skrotum } & Normal & Normal \\
\hline \multicolumn{2}{|c|}{ Pubes } & \multicolumn{2}{|c|}{ Jarang } \\
\hline & Pola & \multicolumn{2}{|c|}{ Jajaran genjang } \\
\hline \multicolumn{4}{|c|}{ Interna } \\
\hline \multicolumn{4}{|c|}{$\overline{\text { Testis }}$} \\
\hline$\square$ & Letak & Skrotum & Skrotum \\
\hline$\square$ & Volume (mL) & 6 & 6 \\
\hline$\square$ & Konsistensi & Soft & Soft \\
\hline$\square$ & Nyeri & - & - \\
\hline \multicolumn{4}{|c|}{ Epididimis } \\
\hline$\square$ & Ukuran & Normal & Normal \\
\hline$\square$ & Konsistensi & Kenyal & Kenyal \\
\hline$\square$ & Permukaan & Rata & Rata \\
\hline$\square$ & Nyeri & - & - \\
\hline$\square$ & Massa & - & - \\
\hline \multicolumn{2}{|c|}{ Funikulus Spermatikus } & Normal & Normal \\
\hline$\square$ & Vas deferens & + & + \\
\hline$\square$ & Varikokel & - & - \\
\hline
\end{tabular}

Pemeriksaan penunjang yang dilakukan pada pasien ini adalah pemeriksaan laboratorium dan radiologi. Pada pemeriksaan laboratorium, didapatkan hasil sesuai Tabel 2. Untuk pemeriksaan radiologi, pasien menjalani empat kali pemeriksaan radiologi. Ultrasonografi (USG) mammae bilateral pada tanggal 23 Desember 2014, menunjukkan gambaran pada Gambar. Hasil interpretasi bagian radiologi menyebutkan bahwa (a) kanan: tak tampak lesi solid/kistik, intensitas echo parenkim normal, tak tampak distorsi jaringan, tebal jaringan payudara kanan 2,67 cm, tampak ektasis duktal di retroareola; (b) kiri: tak tampak lesi solid/kistik, intensitas echo parenkim normal, tak tampak distorsi jaringan, tebal jaringan payudara kanan 2,79 cm, tampak ektasis duktal di retroareola; aksila kanan-kiri: tak tampak pembesaran lymphnode. Hasil pemeriksaan menyokong gambaran ginekomasti bilateral dengan ektasis duktal bilateral.
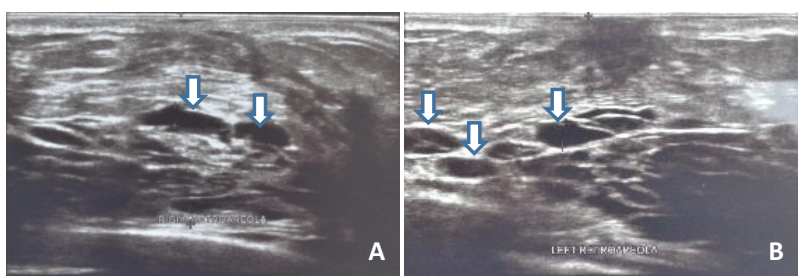

Gambar 2. Hasil USG mammae pasien. (A) USG mamma kanan dan (B) USG mamma kiri. Keduanya menunjukkan adanya pelebaran duktal di area retroareola (panah putih)

Hasil interpretasi bagian radiologi untuk USG abdomen pada tanggal 23 Desember 2014 menunjukkan bahwa (a) Hepar ukuran normal, sudut tajam, tepi rata, intensitas echo parenkim tampak normal homogen, tak tampak pelebaran intra/extrahepatic bile duct (IHBD/EHBD), vena porta/vena hepatika tampak normal, tak tampak nodul/kista/massa; (b) kandung empedu ukuran normal, tak tampak pelebaran dinding, tampak batu ukuran 1,19 $\mathrm{cm}$; (c) lien ukuran normal, intensitas echo parenkim tampak normal, tak tampak massa/kista; (d) pankreas ukuran normal, intensitas echo parenkim tampak normal, tak tampak pelebaran duktus pankreatikus, tak tampak massa/kista/kalsifikasi; (e) ginjal kanan ukuran normal, intensitas echo korteks tampak normal, batas sinus korteks tampak jelas, tak tampak ektasis sistem pelviokalseal, tak tampak batu/kista/massa; (f) ginjal kiri ukuran normal, intensitas echo korteks tampak normal, batas sinus korteks tampak jelas, tak tampak ektasis sistem pelviokalseal, tak tampak batu/kista/massa; (g) buli terisi cukup cairan, tak tampak penebalan dinding, tak tampak massa/batu/kista; (h) prostat ukuran normal, intensitas echo parenkim tampak normal, tak tampak massa/kalsifikasi; (i) Tak tampak intensitas echo cairan bebas ekstraluminal di cavum abdomen. Gambaran mengarahkan adanya kolelitiasis, tidak tampak tanda-tanda tumor adrenal kanan kiri, tidak didapatkan gambaran uterus di cavum pelvis, saat ini hepar/lien/pankreas/ginjal kanan kiri/buli/prostat tak tampak kelainan.

Hasil interpretasi bagian radiologi untuk USG testis bilateral pada tanggal 19 Januari 2015 menunjukkan gambaran, (a) Skrotum kanan tampak gambaran testis, ukuran normal, tampak intensitas echo cairan minimal di dalam skrotum, pada doppler vaskularisasi intra testis tampak normal; (b) Skrotum kiri tampak gambaran testis, ukuran normal, tampak intensitas echo cairan minimal di dalam skrotum, pada doppler vaskularisasi intra testis tampak normal. Hasil mengarahkan testis kanan kiri tak tampak kelainan (Gambar 3).

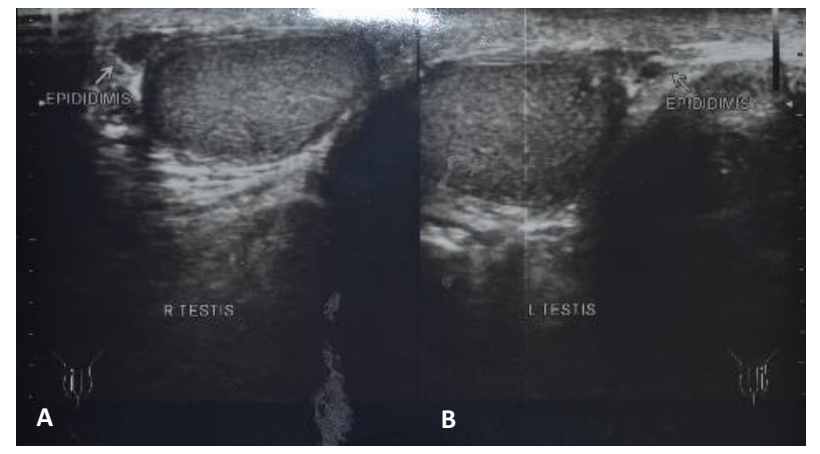

Gambar 3. Hasil USG testis kanan (A) dan kiri (B) yang menunjukkan hasil testis normal

Hasil interpretasi bagian radiologi untuk magnetic resonance imaging (MRI) kepala dengan kontras pada tanggal 28 Januari 2015 yang dibaca ulang pada 16 Maret 2017 seperti pada Gambar 4: (a) Tampak lesi, dengan ukuran $0,4 \mathrm{~cm} \times 0,2 \mathrm{~cm} \times 0,2 \mathrm{~cm}$ yang isointens pada T1W1 dan T2W1 yang pada pemberian kontras (dynamic sequence) tampak hypoattenuating dibandingkan parenkim kelenjar hipofisis normal; (b) Sulkus dan girus tampak normal. Sistem ventrikel dan sisterna tampak baik. Tak tampak deviasi struktur midline. Pons dan serebellum tampak baik. Mastoid, orbita, dan sinus paranasalis kanan kiri tampak baik; (c) DWI: tak tampak restricted diffusion area; (d) MR angiography: circulus Willisi tampak patent, tak tampak aneurisma maupun malformasi vaskuler. Tampak hipoplasi segmen A1 ACA kanan; (e) Kesan: temuan di atas dapat merupakan gambaran suatu mikroadenoma hipofisis. Terdapat hipoplasi segmen A1 


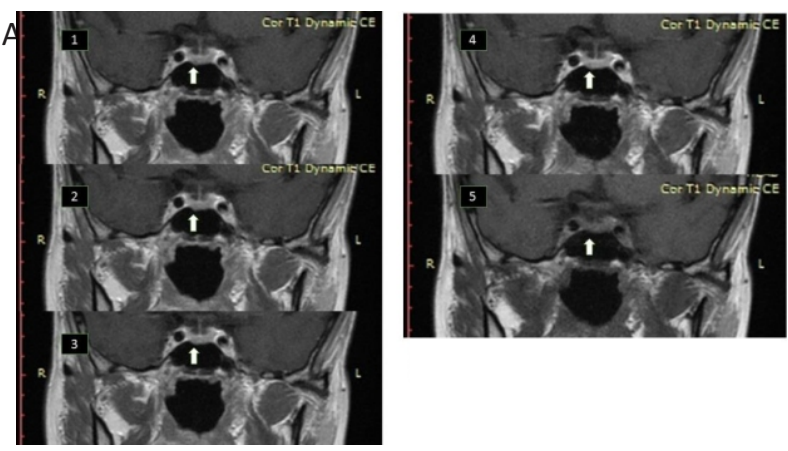

Gambar 4. Hasil MRI kepala dengan kontras menunjukkan hipoatenuasi (delayed contrast enhancement) pada hipofisis kanan (panah putih). Potongan sekuens (urutan sesuai angka) MRI pada coronal dynamic contrast enhancement.

Dari hasil pemeriksaan laboratorium, didapatkan profil hormon hipofisis anterior dalam batas normal, kecuali hormon gonadotropin yang mengalami penurunan kadar yang signifikan. Kadar hormon testosteron dalam darah juga terukur rendah. Hasil pemeriksaan laboratorium ini kemudian dijadikan dasar untuk melakukan pemeriksaan radiologi MRI yang menegakkan diagnosis mikroadenoma hipofisis.

\section{DISKUSI}

Ginekomasti merupakan kondisi yang fisiologis, namun dapat menjadi petanda adanya kondisi patologis $(1,3)$. Selain itu, perlu dibedakan dengan kondisi lipomasti, yaitu jaringan lemak berlebih. Beberapa hal penting yang perlu dievaluasi sehubungan dengan ginekomasti adalah (9): (1) apakah terdapat nyeri? (2) apakah ginekomasti ataukah lipomasti? (3) adakah tanda-tanda keganasan? (4) adakah tanda-tanda tumor testis? (5) apakah penyebab ginekomasti dapat diidentifikasi? (6) apakah pasien terganggu dengan ginekomasti?

Pada kondisi ginekomasti patologis, patogenesis yang paling sering terjadi adalah faktor hormonal. Ketidakseimbangan hormon ini perlu ditelaah lebih lanjut, apakah terdapat penyakit atau kondisi patologis lain yang menjadi pemicu. Ketidakseimbangan hormon melibatkan rasio testosteron dan estradiol (1,3). Terdapat beberapa kondisi organik tertentu yang dapat mengganggu

Tabel 2. Hasil pemeriksaan laboratorium

\begin{tabular}{|c|c|c|c|c|c|c|}
\hline Parameter & $23 / 12 / 14$ & $19 / 1 / 15$ & $20 / 1 / 15$ & $28 / 1 / 15$ & $27 / 3 / 15$ & Nilai Normal \\
\hline Hemoglobin $(\mathrm{g} / \mathrm{dL})$ & 14,6 & & & & & $13,5-17,5$ \\
\hline Leukosit $\left(/ \mathrm{mm}^{3}\right)$ & 9.240 & & & & & $4.000-11.000$ \\
\hline Trombosit $\left(/ \mathrm{mm}^{3}\right)$ & 278.000 & & & & & $150.000-450.000$ \\
\hline Glukosa Darah Puasa (mg/dL) & 102 & & & & & $<100$ \\
\hline AST (U/L) & 7 & & & & & $15-37$ \\
\hline $\operatorname{ALT}(\mathrm{U} / \mathrm{L})$ & 17 & & & & & $12-78$ \\
\hline HbA1C (\%) & & & & & 6,6 & $<6,5$ \\
\hline BUN (mg/dL) & 8 & & & & & $7-18$ \\
\hline Kreatinin (mg/dL) & 0,4 & & & & & $0,6-1,3$ \\
\hline Albumin (g/dL) & 4,1 & & & & & $3,4-5,0$ \\
\hline Kolesterol Total $(\mathrm{mg} / \mathrm{dL})$ & & & & & 283 & $0-200$ \\
\hline LDL-kolesterol & & & & & 170 & $0-130$ \\
\hline HDL-kolesterol & & & & & 39 & $40-60$ \\
\hline Trigliserida & & & & & 325 & $30-200$ \\
\hline $\mathrm{SI}(\mu \mathrm{g} / \mathrm{dL})$ & & & & & 51 & $50-175$ \\
\hline TIBC ( $\mu \mathrm{g} / \mathrm{dL})$ & & & & & 397 & $250-450$ \\
\hline \multicolumn{7}{|l|}{ Ferritin (ng/mL) } \\
\hline PSA (ng/mL) & & & & & 0,26 & $<4$ \\
\hline TSH ( $\mu \mathrm{lU} / \mathrm{mL})$ & 1,421 & & & & & $0,35-5,5$ \\
\hline FT4 (ng/dL) & 1.51 & & & & & $0.89-1.76$ \\
\hline Kortisol ( $\mu \mathrm{g} / \mathrm{dL})$ & 2488 & & & & & $43-7) 4$ \\
\hline Testosteron (ng/dL) & 22,65 & & 6,22 & $1.201,94$ & 80,07 & $241-827$ \\
\hline $\mathrm{LH}(\mathrm{mlU} / \mathrm{mL})$ & & & $<0,07$ & & $<0,07$ & $1,5-9,3$ \\
\hline $\mathrm{FSH}(\mathrm{mlU} / \mathrm{mL})$ & & & $<0,3$ & & 0,90 & $1,4-18,1$ \\
\hline Estradiol (pg/mL) & & 20,39 & & & $<11,80$ & $15-60$ \\
\hline Progesteron $(\mathrm{ng} / \mathrm{mL})$ & & 0,11 & & & & $0,1-1$ \\
\hline Prolaktin & & 8,65 & & & 19,87 & $2,1-17,7$ \\
\hline B-HCG (mlU/mL) & & & & $<2,00$ & & $<3,00$ \\
\hline $\mathrm{GH}(\mathrm{ng} / \mathrm{mL})$ & & & & & 5,17 & $0,06-40$ \\
\hline ACTH $(\mathrm{pg} / \mathrm{mL})$ & & & & & 10,5 & $\leq 46$ \\
\hline DHEAS $(\mu \mathrm{g} / \mathrm{dL}$ & & & & & 46,8 & $80-560$ \\
\hline Kalium (mmol/L) & 4,2 & & & & & $3,5-4,5$ \\
\hline Natrium (mmol/L) & 110 & & & & & 125.115 \\
\hline Klorida (mmol/L) & 109 & & & & & $95-105$ \\
\hline
\end{tabular}

Keterangan: Aspartate Aminotransferase (AST), Alanine Aminotransferase ( ALT), Hemoglobin A1c (HbA1C), Blood Urea Nitrogen (BUN), Low-Density Lipoprotein (LDL), High-Density Lipoprotein (HDL), Serum Iron (SI), Total Iron Binding Capacity (TIBC), Prostate-Specific Antigen (PSA), ThyroidStimulating Hormone (TSH), Free-Thyroxine (T4) (FT4), Luteinizing Hormone (LH), Follicle-Stimulating Hormone (FSH), Beta-Human Chorionic Gonadotropin (B-HCG), Growth Hormone (GH), Adreno-Corticotropin Hormone (ACTH), Dehydroepiandrosterone Sulfate (DHEAS) 
keseimbangan hormon, dengan menurunkan kadar hormon testosteron dan/atau meningkatkan kadar hormon estradiol, salah satunya adalah gagal testis primer.

Secara klinis, tahapan penting dalam menangani pasien ginekomasti adalah menegakkan diagnosis ginekomasti, menentukan etiologi sehingga dapat menentukan pilihan manajemen penanganan, dan menentukan derajat keparahan (3). Pada kasus ginekomasti, peran anamnesis dan pemeriksaan fisik memegang peranan penting.

Pada pasien ini, tidak ditemukan adanya gangguan endokrin sebelumnya. Pasien merupakan pasien dewasa dengan fungsi seksual dan hormon reproduksi yang normal, dibuktikan dengan riwayat keluarga, yaitu menikah dengan tiga anak. Setelah kelahiran anak ketiga, pasien mulai merasakan perubahan pada kedua payudaranya. Sejak satu tahun terakhir, pasien mulai merasakan penurunan libido dan perubahan seksual sekunder berupa suara, kulit, dan garis rambut. Pasien menyangkal mengonsumsi obat hormon atau suplemen herbal. Pada pemeriksaan fisik, kedua payudara membesar (grade 2) dengan pembesaran kelenjar payudara konsentrik pada areola, konsistensi kenyal, tanpa nyeri, dan ada cairan berwarna putih yang keluar dari puting bila payudara dipijat (galaktorhea). Tidak didapatkan massa pada payudara ataupun retraksi pada kulit dan puting payudara. Pasien memiliki body mass index (BMI) 22,03 kg/m².

Berdasarkan riwayat dan pemeriksaan fisik, dapat ditegakkan diagnosis ginekomasti. Tahap berikutnya adalah mencari etiologi ginekomasti. Jaringan kelenjar payudara laki-laki memiliki reseptor estrogen dan androgen. Kedua faktor ini dapat dipengaruhi oleh meningkatnya aktivitas estrogen, atau menurunnya aktivitas androgen, atau kombinasi dari keduanya. Faktor dari jaringan lokal di payudara laki-laki juga sangat berpengaruh terhadap patogenesis ginekomasti. Diantaranya meningkatnya produksi lokal dari estrogen yang akan meningkatkan aktivitas aromatase di payudara, menurunkan inaktivasi estrogen, menurunkan produksi testosteron dari androstenedion. Selain itu, perubahan dari reseptor juga berpengaruh $(1,3)$.

Hiperprolaktinemia merupakan salah satu patogenesis yang melibatkan hormon dan cukup menjadi pertimbangan meskipun jarang ditemukan pada pasien ginekomasti (10). Hiperprolaktinemia dapat menyebabkan ginekomasti melalui mekanisme hipogonadisme sentral. Banyak laki-laki dengan ginekomasti memiliki serum prolaktin yang normal, dan tidak semua laki-laki dengan hiperprolaktinemia akan menderita ginekomasti.

Pada pasien ini, patogenesis yang dapat dipertimbangkan adalah hiperprolaktinemia. Hal ini disebabkan adanya galaktorhea. Galaktorhea menunjukkan adanya kemungkinan hiperprolaktinemia (11). Prolaktin dan reseptor progesteron dapat saling berinteraksi. Bila terjadi peningkatan prolaktin akan memicu peningkatan ekspresi reseptor progesteron dan menurunkan ekspresi reseptor androgen. Progesteron sendiri memiliki peran penting dalam diferensiasi lobuloalveolar pada payudara perempuan. Namun, peran progesteron pada payudara laki-laki belum banyak dapat dijelaskan. Diduga, progesteron dapat bersinergis dengan insulin-like growth factor-1 (IGF-1) dan menstimulasi morfogenesis saluran kelenjar payudara (3). Pada pasien ini diperlukan pemeriksaan konfirmasi kadar prolaktin, karena terjadi perubahan yang signifikan pada pemeriksaan pertama bulan Januari 2015 dengan pemeriksaan kedua pada bulan Maret 2015.

Pemeriksaan radiologi dapat dilakukan untuk menemukan etiologi dari ginekomasti. Ultrasonografi testis dan payudara diperlukan untuk menyingkirkan dugaan kemungkinan keganasan dan mengetahui fungsi anatomi testis dan payudara. Ultrasonografi abdomen diperlukan untuk mengetahui adanya tanda-tanda penyakit sistemik yang mungkin terlewatkan saat anamnesis dan pemeriksaan fisik, seperti tumor adrenal maupun kelainan pada hati $(1,2,3,10)$.

Pada pasien ini, pemeriksaan laboratorium menunjukkan fungsi hati, ginjal, dan tiroid yang normal. Terjadi penurunan kadar hormon testosteron, FSH, LH, estradiol, dan progesteron. Pada pemeriksaan ultrasonografi payudara, abdomen, dan testis ditemukan ginekomasti bilateral dengan ektasis duktal bilateral, kolelitiasis, dan testis normal. Dari hasil pemeriksaan ini, dapat ditegakkan diagnosis ginekomasti disebabkan hipogonadotropin hipogonadisme.

Kondisi hipogonadotropin hipogonadisme atau disebut hipogonadisme sekunder dapat disebabkan gangguan pada hipotalamus dan/atau hipofisis. Sebagian besar kasus hipogonadisme sekunder merupakan efek dari adanya kondisi patologis dari hipofisis (12). Patogenesis dari hipogonadisme sekunder juga dapat merupakan kelainan kongenital seperti Sindroma Kallman. Tetapi kondisi ini biasanya memberikan tanda dan gejala pada pasien yang lebih muda. Untuk memastikan fungsi dari hipofisis, maka diperlukan pemeriksaan profil hormon hipofisis anterior. Dapat pula dilakukan pemeriksaan radiologi tambahan, yaitu MRI $(4,7)$.

Pada profil hormon hipofisis anterior pasien ini, ditemukan semua profil hormon normal, kecuali hormon FSH dan LH yang menurun. Pada hasil pemeriksaan MRI kepala dengan kontras ditemukan lesi berukuran $0,4 \mathrm{~cm} \times 0,2 \mathrm{~cm} \times 0,2 \mathrm{~cm}$ pada hipofisis.

Tumor hipofisis merupakan tumor jinak yang muncul dari kelima tipe sel hipofisis anterior (laktotropin, gonadotropin, somatotropin, kortikotropin, dan tirotropin) (8). Tumor ini memiliki angka kejadian $10-15 \%$ dari semua tumor intrakranial. Sekitar 30\% dari tumor hipofisis merupakan tumor non-fungsional, yang tidak menyebabkan efek hipersekresi hormon seperti Cushing's disease, hiperprolaktinemia, atau akromegali (13). Secara klinis, tumor hipofisis akan memberikan gejala melalui dua mekanisme, hipersekresi atau defisiensi hormon, dan manifestasi penekanan massa tumor terhadap area sekitarnya, seperti gangguan visual atau nyeri kepala. Tujuan utama terapi dari tumor hipofisis adalah menghilangkan efek penekanan massa tumor dan/atau menormalisasi kadar hormon yang terpengaruh oleh tumor (8).

Pasien tidak mengalami keluhan yang berkaitan dengan penekanan massa tumor, yaitu gangguan visual maupun nyeri kepala. Keluhan dominan adalah perubahan tanda seksual sekunder dari laki-laki menjadi seperti perempuan. Hal ini dapat disebabkan oleh penurunan kadar hormon gonadotropin yang memiliki efek pada penurunan kadar hormon testosteron.

Secara ringkas, pada kasus ini, pasien mengalami kondisi klinis berupa ginekomasti dan galaktorhea dengan adanya 
perubahan suara, kulit, dan garis rambut menyerupai perempuan. Profil hormon menunjukkan adanya penurunan hormon gonadotropin, testosteron, estradiol, serta progesteron. Hasil USG testis normal dan USG kedua payudara menunjukkan adanya ektasis duktal bilateral. Pemeriksaan MRI menunjukkan adanya kemungkinan gambaran mikroadenoma hipofisis. Patogenesis ginekomasti pada pasien ini adalah kondisi hipogonadotropin hipogonadisme, atau hipogonadisme sekunder. Kondisi klinis ini ditandai dengan adanya penurunan hormon testosteron yang disebabkan oleh adanya proses patologis di sentral atau otak, pada kasus ini, mikroadenoma hipofisis. Adenoma ini menyebabkan penurunan kadar hormon gonadotropin.

\section{DAFTAR PUSTAKA}

1. Narula HS and Carlson HE. Gynecomastia. Endocrinology and Metabolism Clinics of North America. 2007; 36(2): 497-519.

2. Permatasari N, Subandi S. Pengaruh Ekstrak Jintan Hitam terhadap MDA dan Sel Spermatogonium Tikus yang Dipapar Asap Rokok Kretek Subakut. Jurnal Kedokteran Brawijaya. 2013 Apr 27;26(3):161-5.

3. de Barros ACSD and Sampaio MDCM. Gynecomastia: Physiopathology, Evaluation and Treatment. Sao Paulo Medical Journal. 2012; 130(3): 187-197.

4. Bhasin S, Cunningham GR, Hayes FJ, et al. Testosterone Therapy in Men with Androgen Deficiency Syndromes: An Endocrine Society Clinical Practice Guideline. The Journal of Clinical Endocrinology \& Metabolism. 2010; 95(6): 25362559.

5. Nieschlag E and Simoni M. Endocrine Laboratory Diagnosis. In: Nieschlag E, Behre HM, and Nieschlag $S$ (Eds). Andrology: Male Reproductive Health and Dysfunction. Berlin: Springer-Verlag Berlin Heidelberg. 2010; p. 109.

6. Silveira LF and Latronico AC. Approach to the Patient with Hypogonadotropic Hypogonadism. The Journal of Clinical Endocrinology \& Metabolism. 2013; 98(5): 1781-1788.
Manajemen yang direkomendasikan untuk pasien adalah pemberian terapi pengganti testosteron. Terapi ini diperlukan untuk meningkatkan kualitas hidup sebagai laki-laki serta mengembalikan libido dan menahan laju perubahan tanda seksual sekunder. Rekomendasi berikutnya adalah konsultasi dengan Departemen Bedah Plastik untuk terapi ginekomasti. Kondisi ginekomasti menahun merupakan salah satu faktor risiko kondisi histologis jaringan payudara berubah menjadi fibrotik dan memiliki respon minimal terhadap terapi medikamentosa. Rekomendasi berikutnya adalah konsultasi dengan Departemen Bedah Saraf untuk prosedur pengangkatan tumor hipofisis.

7. Muneer A. Hypogonadism: An Underdiagnosed Condition. Trends in Urology, Gynaecology \& Sexual Health. 2010; 15(2): 14-17.

8. Lake MG, Krook LS, and Cruz SV. Hypophysis Adenomas: An Overview. American Family Physician. 2013; 88(5): 319-327.

9. Carlson HE. Approach to the Patient with Gynecomastia. The Journal of Clinical Endocrinology \& Metabolism. 2011; 96(1): 15-21.

10. Dickson G. Gynecomastia. American Family Physician. 2012; 85(7): 716-722.

11. Zarotsky V, Huang MY, Carman W, Morgentaler A, Singhal PK, Coffin D, Jones TH. Systematic literature review of the epidemiology of nongenetic forms of hypogonadism in adult males. Journal of Hormones. 2014; 2014:1-17.

12. Dohle GR, Arver S, Bettocchi C, Jones TH, Kliesch S, and Punab M. Guidelines on Male Hypogonadism. European Association of Urology. (Online) 2015. http://uroweb.org/wp-content/uploads/EAUGuidelines-Male-Hypogonadism-2015.pdf. Diakses November 2016.

13. Muh CR and Oyesiku NM. Non-Functioning Adenomas: Diagnosis and Treatment. In: Swearingen $B$ and Biller BMK (Eds). Diagnosis and Management of Hypophysis Disorders. Totowa New Jersey: Humana Press; 2008: pp. 271-288. 